\title{
EQUITABLE ACCESS TO HEALTH SERVICE IN BANYUWANGI
}

\author{
Lusi Herawati \\ Student in Management of Infrastructure and Community Development \\ Graduate School Gadjah Mada University and Officer in \\ Local Government of Banyuwangi regency \\ Email: luchi3h3ra@yahoo.com
}

\section{Sunyoto Usman}

Lecturer and Program Director in Management of Infrastructure and Community Development Graduate School and Sociology Department

Faculty of Social Political Science Gadjah Mada University

Senior Researcher in Center for Transportation and logistics Studies UGM

Email: sunyotousman@yahoo.com

\author{
Mark Zuidgeest \\ Lecturer in Management of Infrastructure Community Development \\ Graduate School Gadjah Mada University \\ Lecturer in Faculty of Geo-Information Science and Earth Observation \\ University of Twente Netherlands \\ Email: zuidgeest@itc.nl
}

\begin{abstract}
ABSTRAK
Layanan kesehatan berkeadilan merupakan hak dasar bagi warganegara dan harus dipenuhi oleh pemerintah. Penelitian ini menganalisis perbedaan akses kefasilitas kesehatan (rumah sakit dan Pusat Kesehatan Masyarakat - Puskesmas) di Kabupaten Banyuwangi. Identifikasi akses masyarakat terhadap fasilitas kesehatan dilakukan dengan indikator waktu perjalanan dan pilihan moda transportasi. PerangkatlunakFlowmap digunakan untuk menganalisis catchment area masing-masing fasilitas kesehatan menggunakan berbagai moda transportasi: becak dan angkutan umum untuk kaum miskin (poor group), dan sepeda motor dan mobil untuk non-poor group dengan waktu perjalanan 30, 60 dan di luar 60 menit. Penelitian ini menunjukkan bahwa terdapat perbedaan aksesibilitas antara poor group dan non-poor group. Akses poor group ke fasilitas kesehatan lebih rendah dibandingkan non-poor group. Kondisi ini terjadi dikarenakan kebijakan pemerintah dalam pemerataan akses ke fasilitas kesehatan tidak memperhatikan aksesibilitas masyarakat miskin.
\end{abstract}

Kata kunci: fasilitas kesehatan, aksesibilitas, poor

\begin{abstract}
Equitable health care is a basic right for citizens and must be fulfilled by the government. This research analyzed community discrepancy in access to reach health services in public hospitals and Puskesmas (health centers) in Banyuwangi Regency. This research identified community accessibility to health facilities services using travel time and transport modes choice as indicators. Flowmap tool is used to analyze catchment area of each health facility using different transport modes choice:
\end{abstract}


becak and public transport for poor group and motorcycle and car for non-poor group with different travel time within 30, 60 and more than 60 minutes. It is concluded that there was an accessibility difference between poor and non-poor group. The accessibility to the health facilities of poor group was lower than non-poor group. This condition occurred because the government policy of equitable access to health service facility did not pay attention to accessibility of poor group.

Keyword: health facility, accessibility, poor

\section{INTRODUCTION}

Getting equity and adequate health care service is a basic right for citizens that must be fulfilled by governments. To realize this principal, the Indonesian government issues various policies in the health sector, such as providing facilities to improve services. The purpose of health facilities provision is to facilitate community to get individual health service including promotive, preventive, curative, and rehabilitative health service so that they can reach the better health status. Infrastructures such as road and bus networks are developed to make it easier to access health facilities.

In the other side, poor people are particularly disadvantaged when it comes to access hospitals. Hospitals usually are located relatively far away for mostly people, as they only provided in a small number. On the other side many people lack of transport access. Therefore, they have to spend extra money and time to reach hospitals. This condition causes the health status of higher income people better than the poor do. The rich can go to better hospital to get better health service so they can get quality as well as the easiness and quality of access. It is true if location is not the only factor that causes the gap. Other factor such as financial affordability, information on health condition, the health resources, also community health behaviors have significant impact to create the gap.

While health facilities and service is available at the level of sub district, equity of this health services may not be going well. Service coverage (number of population served) in general hospital and Puskesmas in some districts is very high if compare with the other. The main objective of the research was to analyze equity in access to health service facilities especially for different social economic groups in Banyuwangi. Further, this research tried to match the infrastructure and facility type in the supply side and the user and patient type in the demand side and propose and quantify strategies to increase accessibility of health facility for people in order to get a more equitable health services provision.

\section{Conceptual Framework}

The conceptual framework in Figure 1 shows the relationship between health facilities and community begins from supply side (health facilities provision).

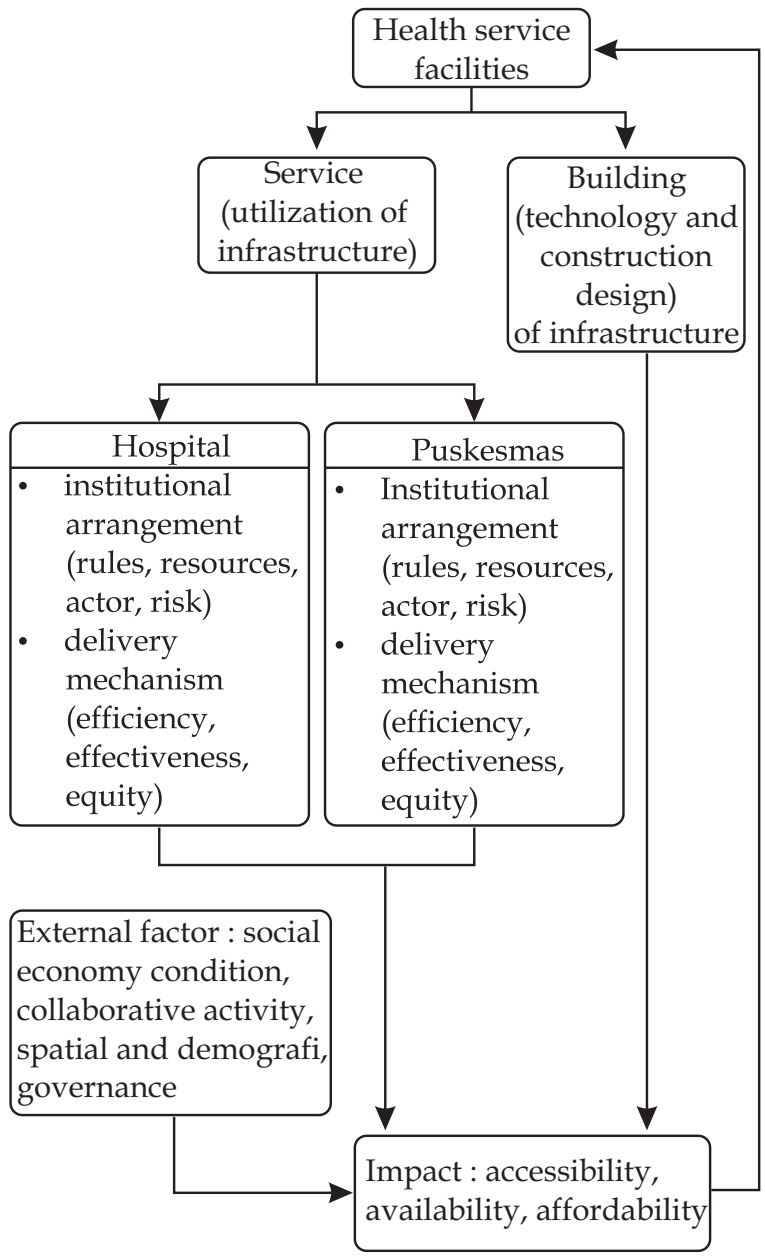

Figure 1.

Conceptual Framework 
Health facilities is defined not only as a building (technology and construction design) but also includes its services. The health service utilization of each level facility is influenced by internal factor which define as institutional arrangement (rules, resources, actor and risk) and delivery mechanism (efficiency, effectiveness and equity). The social economic impacts include increasing accessibility, availability and equity in health service utilization. The health service utilization closely related with external factor such as social economy condition, collaborative activity, spatial and demography, governance.

\section{Study Area Description}

Banyuwangi regency is located at the eastern part of East Java Province with an area of $5,782.50 \mathrm{~km}^{2}$. Banyuwangi regency consists of $24 \mathrm{sub}$ districts and 217 villages (189 desa and 28 kelurahan) inhabited by 1,587,403 people (2009) with a population growth rate of $0.22 \%$ and density of 275 people $/ \mathrm{km}^{2}$. The Human Development Index (HDI) of this area has improved from year to year, although still under the HDI value of East Java Province (ranked $26^{\text {th }}$ from 38 regencies). This increased because of the improvement of Life Expectancy Index, Education Index, and Purchasing Power Parity.

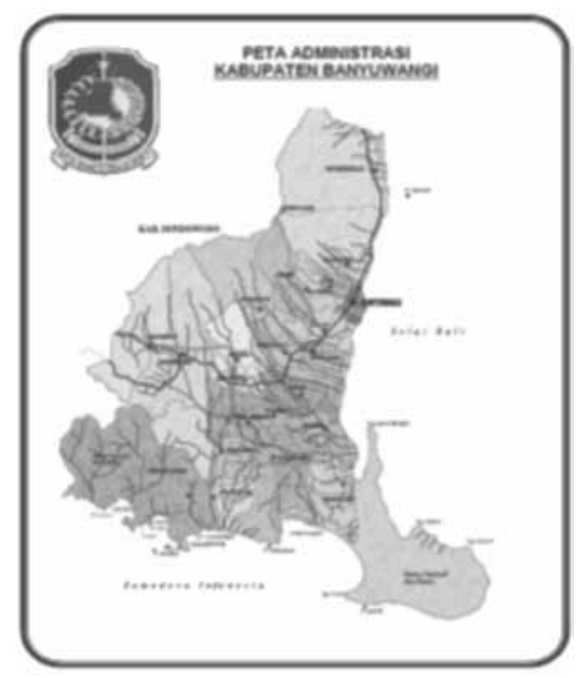

Figure 2.

Administrative Map of Banyuwangi Regency

\section{Limitation}

From many type of health facilities, this research only used general hospital and Puskesmas; and the hospitals that used for analysis in this research are general hospital, public hospital and private hospital. The public transport that used in this analysis is paratransit.

\section{Literature Review}

There are several factors influence the choice of the health facilities service, one of them is the accessibility. Dimension of access differ with different geographical, socio economic and cultural setting (Shresta, 2010). Five dimensions of access are availability, accessibility, affordability, adequacy, and acceptability (Obrist, 2007). Availability means health service facilities in supply side meets clients needs in the demand side. Accessibility refers to the degree of fit between geographical location of hospitals, means to travel and the location of people $\left(t^{\prime}\right.$ Hoen, 2010). Affordability means the prices of services fit the clients' income and ability to pay. Adequacy means the organization of health care meets the clients' expectations. Acceptability means the characteristics of providers match with those of the clients.

Equity in health is defined by WHO as minimizing avoidable disparities in health and its determinants - including but not limited to health care - between groups of people who have different levels of underlying social attributes (income, gender, ethnicity, geography, etc). Equity in health implies that ideally, everyone should have a fair opportunity to attain their full health potential and, more pragmatically, that no one should be disadvantaged from achieving this potential, if it can be avoided (WHO, 1986). The focus of equity in healthcare provision is to ensure that all people have access to a minimum standard of healthcare according to need. Therefore, equity is defined as equal access for equal need, where access refers to the absence of barriers - mainly geographical and financial barriers; and need refers to the capacity to benefit or severity of illness (Zere, 2007). 
There are close relationship between poverty and health status. Poverty and disease affect each other, with a relationship that will never end unless there is an intervention on one or both sides, in poverty or illness. Poverty affects the health of the poor so that people become vulnerable to various kinds of diseases (Figure 3), and an unhealthy community suffers from low productivity and high medical expenditure (JPKM, 2007).

$\begin{aligned} & \text { Malnutrition } \text { Poverty } \\ & \text { Lack of health care } \begin{array}{l}\text { Less capable } \\ \text { of learning } \\ \text { Low productivity } \\ \text { Poor environmental } \\ \text { Initation no }\end{array} \\ & \text { Inavequate } \\ & \text { family saving } \\ & \text { Low quality of life }\end{aligned}$

Illness

Figure 3.

Relationships between Poverty and Illness

\section{Methods}

The data requirement of the research were secondary data (from Public Work Agency, Statistics Office, Regional Development Planning Agency and Health Agency) of availability (data of hospital, puskesmas, and skilled persons), accessibility (location of facilities, travel time, distance, cost, transport modes available, and spatial data), affordability (income, asset, level of education) and utilization of health facility (data of patient).

Location and allocation model that used to analyze accessibility were Flowmap software (developed by University of Utrecht, Netherlands). This tool enable us to find the accessibility of resident to the existing health facilities, total demand that covered by the facilities, and travel time to reach the facilities, also possible to produced several strategies to improve the accessibility of health service. This research used catchment area analysis (to allocate origins to the nearest destination), expansion models (determining the best location of additional service center) and relocation models (determine appropriate site selection of the facilities).

\section{Results}

\section{A. Existing Condition in The Study Area. \\ 1) Existing Condition of Hospital and Puskesmas Services}

Banyuwangi has 6 general hospitals that consists of 2 public hospitals and 4 private hospitals. General hospitals in Banyuwangi have 597 beds (capacity 298,500 inpatients), the ratio between total beds and total population are 1:2,698, when compared with total population are 1:5,538. Compared to poor people, the number of hospital beds used for the calculation is from public hospital because the health insurance for the poor only available at public hospital service. The ratio between total beds of public hospital and total poor are 1:636. The potential demand of general hospital services are coming from women, kids, baby, and poor people Based on the data, there were 45 Puskesmas (health center) in Banyuwangi regency. It consists of 15 inpatient and 30 outpatient, every sub district has at least one Puskesmas. Location of hospital and puskesmas can be seen at Figure 4 .

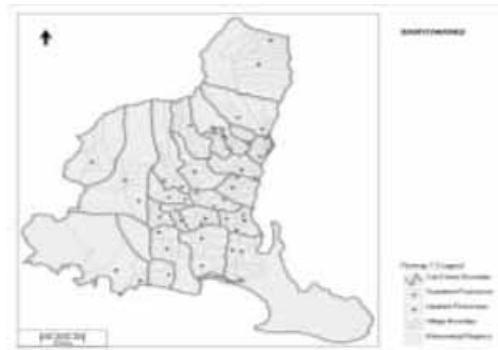

Location of General Hospital

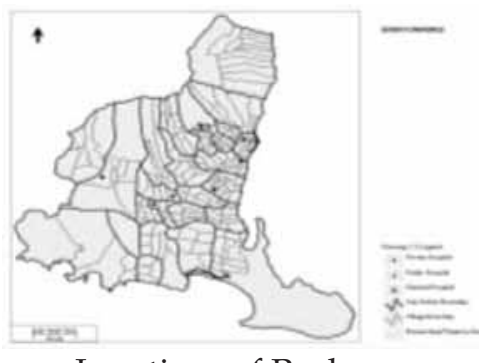

Locations of Puskesmas

Figure 4.

Location of Health Facility 


\section{2) Existing Condition of Access to General Hospital}

The catchment area of general hospital were on travel time 30 minutes (green colour), 30 - 60 minutes (yellow) and more than 60 minutes (red shade colour) with different mode choice such as walking, becak and public transport for the poor, and motorcycle and car for non-poor. Walking, becak and public transport was chosen for the poor's modes because based on one of poverty indicator which published by Statistic Bureau, people put on poor category if they do not have asset more than 500 thousand rupiahs. Figure 5 and Table 1 shows the performance of various transport modes (walking, becak, public transport) to access general hospital, while Figure 6 and table 2 shows the performance of motorcycle and car to access general hospital.

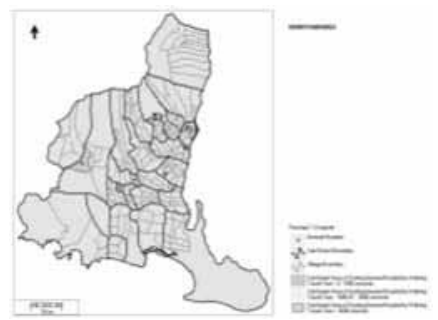

Walking

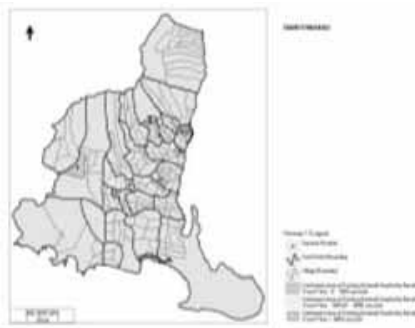

Becak

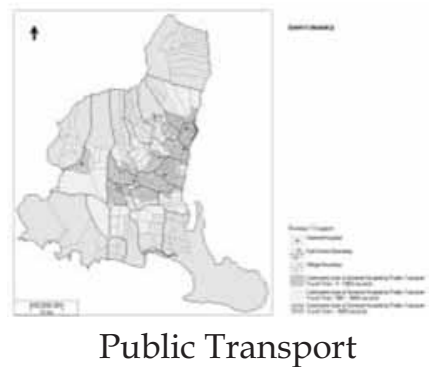

Figure 5.

Catchment Area of General Hospital by Various Transport Modes
Table 1.

Catchment Areas of General Hospital by Various Transport Modes

\begin{tabular}{|c|c|c|c|c|}
\hline \multirow{2}{*}{$\begin{array}{c}\text { Travel } \\
\text { Time to } \\
\text { Facility }\end{array}$} & \multirow{2}{*}{$\begin{array}{c}\text { Catchment } \\
\text { Areas }\end{array}$} & \multicolumn{3}{|c|}{ Transport Modes } \\
\hline & & Walking & Becak & $\begin{array}{c}\text { Public } \\
\text { Transport }\end{array}$ \\
\hline \multirow{4}{*}{$\begin{array}{l}\text { within } \\
30 \\
\text { minutes }\end{array}$} & Number & 78.203 & 128.935 & 643.842 \\
\hline & of Persons & & & \\
\hline & $\begin{array}{l}\text { Number } \\
\text { of Poor }\end{array}$ & 22.415 & 35.322 & 187.630 \\
\hline & Percentage & $4,8 \%$ & $7,6 \%$ & $40,5 \%$ \\
\hline \multirow{4}{*}{$\begin{array}{l}\text { within } \\
30-60 \\
\text { minutes }\end{array}$} & Number & 88.930 & 341.159 & 521.583 \\
\hline & of Persons & & & \\
\hline & $\begin{array}{l}\text { Number } \\
\text { of Poor }\end{array}$ & 25.234 & 97.248 & 155.271 \\
\hline & Percentage & $5,4 \%$ & $21,0 \%$ & $33,5 \%$ \\
\hline \multirow{5}{*}{$\begin{array}{l}\text { more } \\
\text { than } 60 \\
\text { minutes }\end{array}$} & $\begin{array}{l}\text { Number } \\
\text { of Persons }\end{array}$ & 1.413 .308 & 1.110 .347 & 415.016 \\
\hline & $\begin{array}{l}\text { Number } \\
\text { of Poor }\end{array}$ & 415.547 & 330.626 & 120.295 \\
\hline & Percentage & $89,7 \%$ & $71,4 \%$ & $26,0 \%$ \\
\hline & $\begin{array}{l}\text { Total } \\
\text { Persons }\end{array}$ & & & 1.580 .441 \\
\hline & $\begin{array}{l}\text { Total } \\
\text { Poor }\end{array}$ & & & 463.196 \\
\hline
\end{tabular}

Source : Result of Flowmap Analysis, data processed
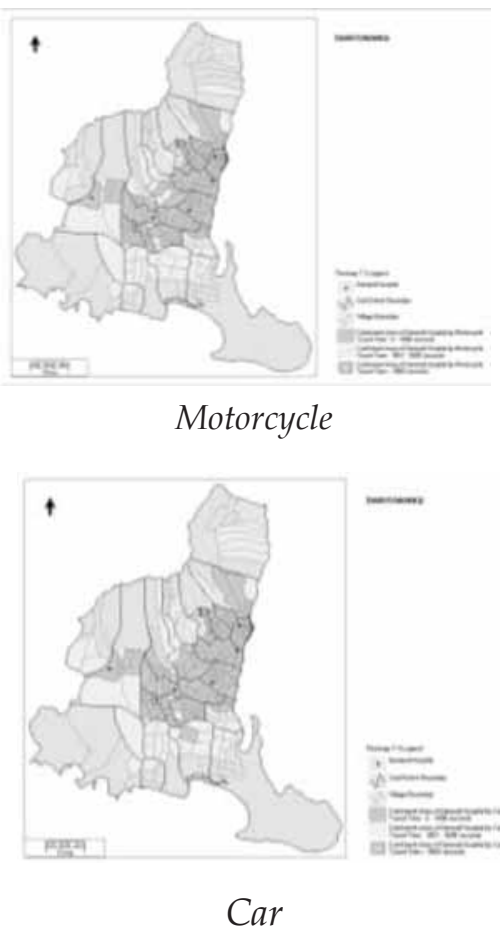

Figure 6.

Catchment Area of General Hospital by Motorcycle and Car 
Table 2.

Catchment Areas of General Hospital by Motorcycle and Car

\begin{tabular}{|c|c|c|c|c|}
\hline \multirow{2}{*}{ Travel Time to Facility } & \multirow{2}{*}{ Catchment Areas } & \multicolumn{3}{|c|}{ Transport Modes } \\
\hline & & Motorcycle & \multicolumn{2}{|r|}{ Car } \\
\hline \multirow[t]{3}{*}{ within 30 minutes } & Number of Persons & 826.480 & 885.482 & \\
\hline & Number of Non-Poor & 572.016 & 616.749 & \\
\hline & Percentage & $51,2 \%$ & $55,2 \%$ & \\
\hline \multirow[t]{3}{*}{$<30-60$ minutes } & Number of Persons & 511.067 & 491.789 & \\
\hline & Number of Non-Poor & 376.008 & 358.521 & \\
\hline & Percentage & $33,7 \%$ & $32,1 \%$ & \\
\hline \multirow{5}{*}{$>60$ minutes } & Number of Persons & 242.894 & 203.170 & \\
\hline & Number of Non-Poor & 169.221 & 141.975 & \\
\hline & Percentage & $15,1 \%$ & $12,7 \%$ & \\
\hline & Total Persons & & & 1.580 .441 \\
\hline & Total Non Poor & & & 1.117 .245 \\
\hline
\end{tabular}

Table 3below shows the accessibility condition of community to general hospital based on transport modes choice.

Table 3.

Accessibility of Population to General Hospital

\begin{tabular}{|c|c|c|c|c|c|c|c|c|}
\hline \multirow{2}{*}{$\begin{array}{c}\text { Travel Time to } \\
\text { Facility }\end{array}$} & \multirow{2}{*}{$\begin{array}{c}\text { Population in } \\
\text { Area }(\%)\end{array}$} & \multicolumn{3}{|c|}{ Transport Modes } & \multicolumn{4}{|c|}{ Poor / Non Poor Based on Transport Modes } \\
\hline & & PT & Mtr & Car & PT / Mtr & Explanation & PT / Car & Explanation \\
\hline \multirow{2}{*}{ within $30 \mathrm{~min}$} & Poor & $40,5 \%$ & - & - & 0,8 & Inequitable & 0,7 & Inequitable \\
\hline & Non Poor & - & $51,2 \%$ & $55,2 \%$ & & Poor Disadv & & Poor Disadv \\
\hline \multirow{2}{*}{$<30-60 \min$} & Poor & $33,5 \%$ & - & - & 1,0 & Equitable & 1,0 & Equitable \\
\hline & Non Poor & - & $33,7 \%$ & $32,1 \%$ & & - & & - \\
\hline \multirow{2}{*}{$>60 \mathrm{~min}$} & Poor & $26,0 \%$ & - & - & 1,7 & Inequitable & 2,0 & Inequitable \\
\hline & Non Poor & - & $15,1 \%$ & $12,7 \%$ & & Poor Disadv & & Poor Disadv \\
\hline
\end{tabular}

Source : Result of Flowmap Analysis, data processed

\section{3) \\ Existing Condition of Access to Existing Puskesmas}

Based on standard, one sub district has at least one Puskesmas and each Puskesmas served 30,000 residents. The result of analysis below were explained about the condition of access to existing condition and the condition of access to ideal Puskesmas based on standard. Catchment area analysis used to know the catchment area of existing Puskesmas in Banyuwangi Regency without considering the ideal condition that 1 puskesmas serves 30,000 people. A catchment area analysis allocated origins to the nearest destination. To measure the accessibility of community to get primary health service in puskesmas was by travel time indicator.

The result of the analysis presented in Table 4 and Figure 7. Figure 7 shows the catchment area of puskesmas within 30 minutes, 30 - 60 minutes and more than 60 minutes travel time with walking, becak, motorcycle, public transport and car. 
Table 4.

Catchment Areas of Existing Puskesmas by Various Transport Modes

\begin{tabular}{lllllll}
\hline \multirow{2}{*}{ Travel time to facilities } & \multirow{2}{*}{ Catchment Areas } & \multicolumn{4}{c}{ Transport Mode } \\
\cline { 3 - 6 } & & Walking & Becak & Public Transport & Motor cycle & Car \\
\hline \multirow{2}{*}{$30 \mathrm{~min}$} & villages accessed & 54 & 83 & 192 & 195 & 195 \\
& Percentage & $25 \%$ & $38 \%$ & $88 \%$ & $90 \%$ & $90 \%$ \\
& persons accessed & 521.461 & 666.411 & 1.395 .688 & 1.410 .243 & 1.410 .243 \\
& Percentage & $33 \%$ & $42 \%$ & $88 \%$ & $89 \%$ & $89 \%$ \\
$30-60 \mathrm{~min}$ & villages accessed & 48 & 81 & 21 & 19 & 18 \\
& Percentage & $22 \%$ & $37 \%$ & $10 \%$ & $9 \%$ & $8 \%$ \\
& persons accessed & 281.561 & 513.999 & 150.277 & 135.722 & 141.454 \\
& Percentage & $18 \%$ & $33 \%$ & $10 \%$ & $9 \%$ & $9 \%$ \\
\hline \multirow{2}{*}{$60 \mathrm{~min}$} & villages accessed & 120 & 53 & 4 & 3 & 4 \\
& Percentage & $56 \%$ & $24 \%$ & $2 \%$ & $1 \%$ & $2 \%$ \\
& persons accessed & 777.419 & 400.031 & 34.476 & 34.476 & 28.744 \\
\hline
\end{tabular}
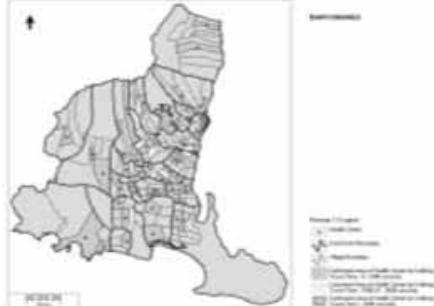

Walking

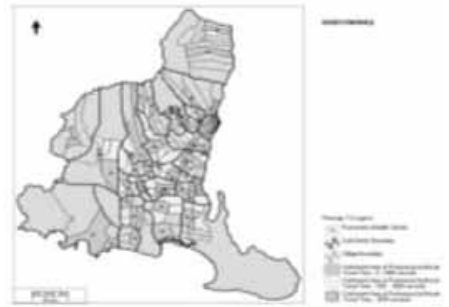

Becak

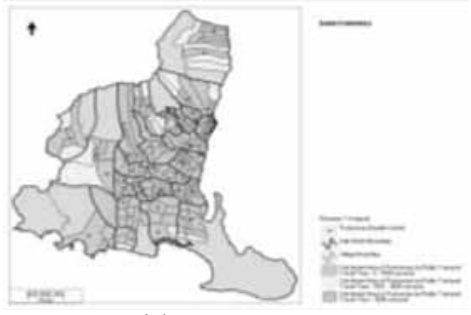

Public Transport

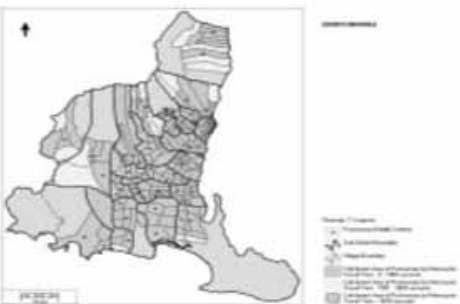

Motorcycle

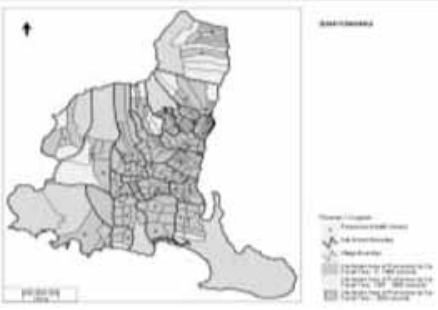

Car

Figure 7.

Catchment Areas of Puskesmas by Various Transport Modes

\section{B. Improve Accessibility to Health}

\section{Service}

\section{1) Expansion Models with Maximum Customer Coverage Model}

We used two kinds of modes choices, public transports for the poor, motorcycle for non-poor with travel time within 30 and 60 minutes, and the forest as an excluded 
location for the new location of health facility. Find best solution set method was selected to find the best location for the new facilities. The result showed that the best location of new general hospital located in Sumberberas Village, Muncar Subdistrict for the public transport and Wringinpitu Village, Tegaldlimo Subdistrict for the motorcycle. The catchment areas of the new system is presented in Table 5.

Table 5.

Catchment Areas of New General Hospital by Various Transport Modes

\begin{tabular}{llll}
\hline \multirow{2}{*}{$\begin{array}{c}\text { Travel time } \\
\text { to facilities }\end{array}$} & \multicolumn{1}{c}{$\begin{array}{c}\text { Catchment } \\
\text { Areas }\end{array}$} & $\begin{array}{c}\text { Transport Mode } \\
\text { Transport }\end{array}$ & Motorcycle \\
\hline Within 30 & $\begin{array}{l}\text { Number } \\
\text { minutes }\end{array}$ & 109 & 142 \\
& $\begin{array}{l}\text { of villages } \\
\text { accessed }\end{array}$ & & \\
& $\begin{array}{l}\text { Percentage } \\
\text { No of persons }\end{array}$ & $50 \%$ & $65 \%$ \\
& $\begin{array}{l}\text { Noccessed } \\
\text { acces }\end{array}$ & $50 \%$ & $62 \%$ \\
& $\begin{array}{l}\text { Percentage } \\
\text { Demand } \\
\text { share of new } \\
\text { system }\end{array}$ & 139,272 & 146,230 \\
& Percentage & $9 \%$ & $9 \%$ \\
\hline
\end{tabular}
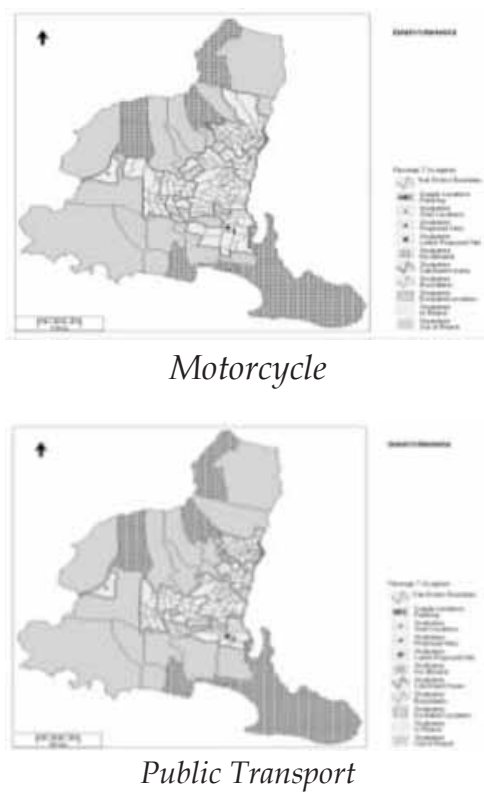

Figure 8.

New General Hospital Reached in 30 minutes by Public Transport and Motorcycle

\section{2) Relocation Models}

Another strategy used to increase the accessibility of community to general hospital was by relocating the existing general hospital. We used two kinds of transport modes, public transport and motorcycle. Figure 9 shows the result of relocation models of general hospital that can be reached within 30 minutes.

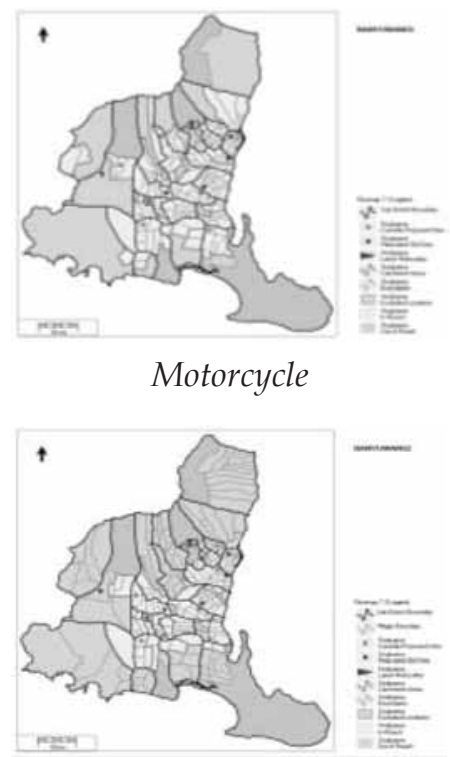

Public Transport

Figure 9.

New Relocated General Hospital Reach in 30 minutes by Public Transport and Motorcycle

Using travel time of public transport indicator, all general hospital had to relocate to other places. The new site of general hospital located at the village following: Sumberberas (Muncar Subdistrict), Purwodadi (Gambiran), Kaligondo (Genteng), Kebondalem (Bangorejo), Pendarungan (Kabat) and Wonosobo (Srono) respectively. With the new location, the demand that covered by the service increased from 643,842 persons $(40.74 \%)$ to $967,964(61.25 \%)$. Usingmotorcycle, thenew siteof general hospital located at the village following: Wringinpitu (Tegaldlimo Subdistrict), Kebondalem (Bangorejo), Wonosobo (Srono), Sumberbaru (Singojuruh), Singotrunan (Banyuwangi) and Bumiharjo (Glenmore) respectively. With the new location, the demand that covered by the 
service was increased from 826,480 persons $(52.29 \%)$ to $1,223,466(77.41 \%)$.

\section{3) Increasing Speed of Vehicle}

Another choice was by increasing the speed of vehicle (Table 6). In this analysis, we only used two kinds of transport modes such as public transport and motorcycle.

Table 6. Speed of Vehicles

\begin{tabular}{llll}
\multicolumn{4}{c}{ Speed of Vehicles } \\
\hline \multirow{2}{*}{ Road Status } & Explanation & \multicolumn{2}{c}{$\begin{array}{c}\text { Speed of Transport } \\
\text { Modes }(\mathrm{km} / \mathrm{h})\end{array}$} \\
\cline { 3 - 4 } & & Motorcycle & PT \\
\hline Central & Arterial Road & 60 & 40 \\
Government & & & 40 \\
Province & Collector road & 60 & 30 \\
Local & Local road & 40 & 20 \\
Other & Village road & 20 & \\
\hline
\end{tabular}

The Figure 10 and Table 7 show the result of the catchment area analysis by using the new speed of vehicles.
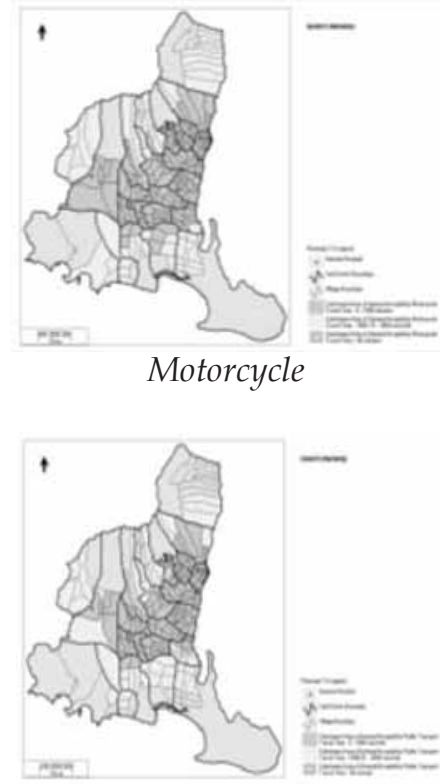

Public Transport

Figure 10

Catchment Area of General Hospital by PT and Motorcycle
Table 7.

Catchment Areas of New General Hospital After Increasing Vehicle Speed

\begin{tabular}{|c|c|c|c|}
\hline \multirow{2}{*}{$\begin{array}{c}\text { Travel } \\
\text { time to } \\
\text { facilities }\end{array}$} & \multirow[b]{2}{*}{$\begin{array}{c}\text { Catchment } \\
\text { Areas }\end{array}$} & \multicolumn{2}{|c|}{ Transport Mode } \\
\hline & & $\begin{array}{l}\text { Public } \\
\text { Transport }\end{array}$ & Motorcycle \\
\hline \multirow[t]{4}{*}{$\begin{array}{l}\text { Within } 30 \\
\text { minutes }\end{array}$} & $\begin{array}{l}\text { No of villages } \\
\text { accessed }\end{array}$ & 139 & 156 \\
\hline & Percentage & $64 \%$ & $72 \%$ \\
\hline & $\begin{array}{l}\text { No of persons } \\
\text { accessed }\end{array}$ & 970,527 & $1,109,719$ \\
\hline & Percentage & $61 \%$ & $70 \%$ \\
\hline \multirow[t]{4}{*}{$\begin{array}{l}30-60 \\
\text { minutes }\end{array}$} & $\begin{array}{l}\text { No of villages } \\
\text { accessed }\end{array}$ & 55 & 52 \\
\hline & Percentage & $25 \%$ & $24 \%$ \\
\hline & $\begin{array}{l}\text { No of persons } \\
\text { accessed }\end{array}$ & 419,305 & 423,791 \\
\hline & Percentage & $27 \%$ & $27 \%$ \\
\hline \multirow[t]{4}{*}{$\begin{array}{l}\text { More than } \\
60 \text { minutes }\end{array}$} & $\begin{array}{l}\text { No of villages } \\
\text { accessed }\end{array}$ & 23 & 9 \\
\hline & Percentage & $11 \%$ & $4 \%$ \\
\hline & $\begin{array}{l}\text { No of persons } \\
\text { accessed }\end{array}$ & 190,609 & 46,938 \\
\hline & Percentage & $12 \%$ & $3 \%$ \\
\hline
\end{tabular}

\section{DISCUSSIONS}

\section{Existing Condition in The Study Area.}

This study found inequity in access to health service facilities occurred in Banyuwangi especially for different social economic groups, poor and non-poor. There were accessibility differences between poor and non-poor group. The accessibility to the health facilities of poor group was lower than non-poor group. This condition occurred because policy of equitable distribution of health facility did not pay attention to accessibility of poor group.

\section{1) Availability of Health Facilities Service}

The existing health facilities in Banyuwangi were not available for every resident of Banyuwangi Regency. The hospital capacity is generally calculated based on the number of beds; indicate the availability of inpatient services. Ideally, two hospital beds are for 1,000 people ( 1 bed for 500 people). Ideally total of beds in general hospital in Banyuwangi are 3.168 beds for 1.583 .918 persons. The beds of general hospital only 
597 beds or the capacity of general hospital in Banyuwangi only for 298,500 inpatients, it means the capacity of general hospital didn't meet the needs. Poor people in the some region had good accessibility to the general hospital in this case private hospital, but they could reach the advance service from the hospital because their health insurance could only be used in public hospital.

Local government must improve the capacity of the public hospital by improving the type of hospital at least from C to B. The beds number of general hospital type $B$ was minimal 200 beds. Improving the number and quality of the service were needed. Local government makes some agreement with private sector to built new general hospital that can deliver affordable service for the poor in order to meet the availability general hospital with the patients especially the poor.

The availability of Puskesmas could be seen from total people have been served. Ideally, 1 Puskesmas serve 30,000 resident (Sabarguna, 2010). The current government policy in establishing the Puskesmas based on administration region, each sub district had at least one Puskesmas. It caused differences in coverage people served. The existing condition, some Puskesmas served under the ideal condition such as Puskesmas Gendoh that served 9,310 persons and Puskesmas Kelir that served 18,025 persons. In the other hand, some Puskesmas served more than 30,000 resident even almost 60,000 residents, this condition far from ideal such as occurred in Puskesmas Kalibaru Kulon that served 61,429 persons and Puskesmas Gitik that served 55,393 persons.

\section{2) Accessibility to Health Service}

The analysis showed that the equitable access to health service was not occurred. It means that hospital service and Puskesmas service more accessible for non-poor group. Non-poor group has good accessibility to reach general hospital in order to get advance health service. The poor's had limitation in transport modes choices. It influenced their accessibility to get health service facility. Catchment area of general hospital accessed by walking was the narrowest among other transport modes that were selected (Figure 5) and it was affected to the number of people was served (Table 1). The areas that located out of catchment area that need travel time more than 60 minutes were wider than the area that could reach the general hospital within 30 minutes and 60 minutes, it means the accessibility of the poor to get health service in general hospital were bad. Using public transport the catchment area of general hospital was wider than walking (Figure 5). It didn't mean the accessibility of the poor better. In order to reach general hospital they were highly dependent with the existence of public transport itself. Limited number of public transport and the quality of public transport service (not punctual, reliable) made accessibility of the poor were getting worse. Even the waiting times were longer than travel time.

Some villages had good accessibility to private hospital, but poor people in that area still had bad access to get health service from hospital because the health insurance could be used only in the public hospital. Some villages had better accessibility to achieve health service (general hospital and puskesmas) than the other, because the location of general hospital tend to be in the main lane of Banyuwangi Regency's road and the location of Puskesmas tend to be in the sub district city center.

\section{Improve Accessibility to Health Service}

To improve accessibility to health facilities service, this research suggested several improvement strategies. First strategy was by adding a new location of hospital by using expansion model. With this model, the people who can reach the general hospital service were increased (Figure 8). The demand share of this new location was high enough. 
Second strategy was by relocating the general hospital. With this model, the people that could reach general hospital service within 30 minutes increased at least 20\% (Figure 9). The last strategy was by increasing the speed of vehicles. With this strategy, catchment area of general hospital service increased, and the service at more than 60 minutes decreased (Figure 10).

From all strategies, the accessibility of people using motorcycle were better than by using public transport. It could be seen from the number of people served by general hospital. From the contribution of demand share, relocation strategy was the best choice to increase the number of people served, but in implementation, this strategy was difficult to do.

\section{Collaborative Action in Health and Transport Sector}

The analysis showed that the relocation model was the best choice in order to increase the people served of general hospital, but in fact, the relocation strategy was the most difficult choice in implementation, especially in Banyuwangi. It was not easy to relocate the general hospital, the infrastructure of facility such as building, medical equipment, laboratory, wastewater treatment plant also another facility. Limitation of land and budget also could produce several new problems. In the other hand, relocation of hospital would take a long time.

In health sector, one strategy that can be done by local government to increase the accessibility was by adding new hospital. In order to add new hospital, local government could improve the existing Puskesmas became hospital. Based on the result of the modeling, Wringinpitu Village in Tegaldlimo Sub district was the best site location that can improve the accessibility. In this case, we could improve the facility and medical resources of Puskesmas Tegaldlimo in Tegaldlimo sub district from inpatient Puskesmas became small hospital. Another way that could be taken were in health sector by improving the facilities and medical resources in existing inpatient Puskesmas so that the inpatient Puskesmas could be become feeder to support hospital service. We could make several zone of location that had bad access to hospital services, and every zone had one feeder for hospital service.

Improving in hospital and Puskesmas networking was also needed. The patients in the emergency condition that lived in the area that had bad accessibility to hospital only call the hospital and the nearest Puskesmas by using mobile facility would took the patient to the nearest supporting Puskesmas so that the patient could be handled faster. Besides improving in health sector, transport sector also had an important role in order to improve accessibility of community to general hospital service. In this sector, it needed collaboration between government, private and community itself. Government had responsibility to provide road in the good condition so the vehicles could easier to go to hospital. Made some regulation about the standard of service for the public transport also encourage the private sector to invest in this sector.

Increasing the number of the public transport and improving in service also needed, problems that usually occurred were the limited number of the modes and bad service of public transport. Arrangement about operational schedule and tariff of the public transport could be done in order to improve the service so people could get the reliable and affordable of public transport service.

The other way was by preparing a special vehicle or car in the village that have bad accessibility to the hospital. This car has a function as a mobile facility for emergency patient to go hospital. This mobile facility can be provided by using government budget or community budget. Development in order to improving accessibility to hospital service must involve all sector, not only health sector also transport sector. Collaboration between 
local governments in this case health agency, hospital administration, transportation agency, development planning agency and public work agency with private sector and community were important to improving accessibility to the hospital service.

\section{Tool Analysis Limitation}

The limitation of the tool was the origin and the destination point locations in Flowmap tool were located in the centroid of the base map area. This condition would affect to the result of the analysis because in fact not all facilities located in the center of the village.

\section{CONCLUSSION}

This research concluded that the accessibility to the health facilities of poor group was lower than non-poor group. This is occurred because policy of equitable distribution of health facility did not pay attention to accessibility of poor group. The inequalities also occurred in order to achieve advance service in general hospital and Puskesmas. Some villages had better accessibility to achieve health service (general hospital and puskesmas) than the other, because the location of general hospital tend to be in the main lane of Banyuwangi Regency's road and the location of Puskesmas tend to be in the sub district city center. In general, the accessibility of community to get primary health care in the Puskesmas service was better than the accessibility to the general hospital service.

Several recommendations offered to solve the problem of accessibility. Firstly, planning of location placement of hospital must pay attention to the poor accessibility so that the location is not on the main line of Banyuwangi Regency. There also needs of regulation of the service area of Puskesmas that was not based on the sub district but based on village so it was possible one puskesmas could served several neighboring village in the different sub district. The policy could be also on improving the networking between hospital and puskesmas. This research also recommends improve at least 5 inpatient puskesmas to become feeders to support hospital service in the area that had bad access to hospital service. Next recommendation is local government need to make formulation related cooperation mechanism with private in health sector especially in new hospital establishment that provide affordable service for poor community. The last recommendation is for the next researcher, can do research in the other dimension of access such as availability, acceptability, affordability, and adequacy because this researches only focus in accessibility of people to reach health facility services. This paper is written from first author's Thesis for Master Programme Management of Infrastructure and Community Development Graduate School Gadjah Mada University.

\section{BIBLIOGRAPHY}

Breukelman, J., Brink, J., et.al, 2009, Manual Flowmap 7.3. Faculty of Geographical Sciences Uthrecth University, The Netherlands: http://flowmap.geo. uu.nl. retrieved December $2^{\text {nd }} 2010$.

Bosanac, Edward M., Parkinson, Rosalind C. and Hall, David S, 1976, Geographic Access to Hospital Care: A 30-Minute Travel Time Standard, Medical Care, Vol. 14, No. 7 (Jul., 1976), pp. 616-624.

JPKM, 2008, Tentang Jaminan Kesehatan Masyarakat. Departemen Kesehatan RI at http:/ / www.ppjk.depkes.go.id. retrieved October $4^{\text {th }} 2010$.

Kabupaten Banyuwangi, 2006, Kabupaten Banyuwangi Dalam Angka Tahun 2006, Bappeda dan BPS Kabupaten Banyuwangi.

,2007, Kabupaten Banyuwangi Dalam Angka Tahun 2007, Bappeda dan BPS Kabupaten Banyuwangi. 
,2008, Kabupaten Banyuwangi Dalam Angka Tahun 2008, Bappeda dan BPS Kabupaten Banyuwangi.

$$
\text { ,2008, Profil Kesehatan }
$$

Kabupaten Banyuwangi Tahun

2008, Dinas Kesehatan Kabupaten Banyuwangi.

,2009, Kabupaten Banyuwangi

Dalam Angka Tahun 2009, Bappeda dan BPS Kabupaten Banyuwangi.

Kabupaten ,2009, Profil Kesehatan
2009, Dinas
Banyuwangi Kesehatan Kabupaten

,2010, Kabupaten Banyuwangi

Dalam Angka Tahun 2010, Bappeda dan BPS Kabupaten Banyuwangi.

,2010, Indeks Pembangunan

Manusia Kabupaten Banyuwangi

Tahun 2010, Bappeda dan Kabupaten Banyuwangi.

Millman, Michael, 1993, Access to Health Care in America, The National Academies Press at: http://www.nap.edu/ catalog/2009.html. retrieved November $3^{\text {rd }} 2010$.

Lampiran Pidato, 2008, Bab XVI Penanggulangan Kemiskinan. Bappenas at http://aparaturnegara.bappenas. go.id. retrieved November $1^{\text {st }} 2010$.

Lindelow, Magnus. 2003, Understanding spatial variation in the utilization of health services: does quality matter?
The World Bank, Centre for Study of African Economies, Oxford University. retrieved November $1^{\text {st }}$ 2010.

Obrist, B., Iteba, N., et.al, 2007, Access to health care in contexts of livelihood insecurity: A framework for analysis and action, PLoS Med 4(10): e308.doi:10.1371/ journal.pmed.0040308.

Sabarguna, Boy S., Soerawidjaya, Resna A, 2010., Health Centre Management in Indonesia. Jakarta : UI-Press.

Shrestha, Jeny, 2010, Evaluation of Access to Primary Healthcare: A Case Study of Yogyakarta, Indonesia, Enschede, ITC. MSc.

T'hoen, Maarten, 2010, Equal Access for a Healthy Community. http://essay. utwente.nl/59692/1/Hoen-M.pdf. retrieved January $20^{\text {th }} 2011$.

World Health Organization, Social justice and equity in health: report on a WHO meeting (Leeds, United Kingdom,1985), Copenhagen, Regional Office for Europe, 1986 (ICP/HSR 804/m02), retrieved October $27^{\text {th }} 2010$.

Zere, Eyob.et.al., 2007, Equity in health and healthcare in Malawi : analysis of trends, BMC Public Health at :http:/ www.biomedcentral.com/14712458/7/78/prepub.

retrieved October $27^{\text {th }} 2010$. 